\title{
ANALISIS KUALITAS PELAYANAN DALAM TATA KELOLA SAMPAH DI KABUPATEN SUMEDANG
}

\author{
Mumuh Muksin ${ }^{1}$, Engkus ${ }^{2}$ \\ ${ }^{1,2}$ UIN Sunan Gunung Djati Bandung \\ Email: mumuh.muksin@uinsgd.ac.id
}

\begin{abstract}
Abstrak
Penelitian ini bertujuan untuk mengetahui kualitas pelayanan pengelolaan sampai pada Dinas Kehutanan dan Lingkungan Hidup Kabupaten Sumedang menggunakan teori kualitas pelayanan Fitzsimmons. Metode yang digunakan peneliti adalah metode kualitatif dengan teknik pengumpulan data berupa observasi, wawancara dan dokumentasi. Teknik analisis data penelitian ini menggunakan model interaktif dari Miles dan Huberman. Berdasarkan hasil penelitian, dimensi tangible belum berjalan dengan baik, kendalanya adalah kendaraan operasional untuk pengangkutan sampah, masih ada kendaraan yang secara fisik tidak baik. Dimensi reliability tidak berjalan dengan baik karena tidak komprehensif dalam pengangkutan sampah di wilayah Kabupaten Sumedang. Dimensi responsive, berjalan dengan baik, sesuai dengan Standard Operating Procedure (SOP). Dimensi assurance, sudah berjalan dengan baik, karena dilihat dari keramahan dan sopan santun yang diberikan kepada masyarakat, sehingga masyarakat merasa terbantu dan tidak memiliki keluhan tentang omong kosong. Dimensi emphaty, telah berjalan dengan baik, karena telah terlihat cukup baik dari sikap resmi para petugas kepada masyarakat yang berjalan baik, sikap tegas terlihat dengan menawarkan sosialisasi para pelayan kepada masyarakat tentang pentingnya membuang sampah menempatkan dan menyebarluaskan informasi tentang dampak buruk ketika penghuni atau masyarakat membuang sampah tidak pada tempatnya.
\end{abstract}

Kata Kunci: Kualitas Layanan, Pengelolaan Limbah, Kesadaran Masyarakat.

\begin{abstract}
This study aims to determine the quality of management services to the Department of Forestry and the Environment of Sumedang Regency using Fitzsimmons service quality theory. The method used by researchers is a qualitative method with data collection techniques such as observation, interviews and documentation. The data analysis technique of this study used an interactive model from Miles and Huberman. Based on the results of the study, tangible dimensions have not gone well, the constraints are operational vehicles for transporting waste, there are still vehicles that are not physically good. The reliability dimension did not work well because it was not comprehensive in the transportation of waste in the Sumedang Regency. Responsive dimension, running well, in accordance with Standard Operating Procedure (SOP). The assurance dimension has been going well, because it is seen from the hospitality and courtesy given to the community, so that the community feels helped and has no complaints about bullshit. The empathy dimension, has been going well, because it has been seen quite well from the official attitude of the officers to the people who are doing well, a firm attitude is seen by offering socialization of the servants to the community about the importance of disposing of trash placing and disseminating information about the adverse effects when occupants or communities dispose of garbage is misplaced.
\end{abstract}

Keywords: Service Quality, Waste Management, Public Awareness. 


\section{A. PENDAhuluaN}

Berdasarkan pengamatan dilapangan yang dilakukan oleh peneliti bahwasannya Dinas Lingkungan Hidup dan Kehutanan Kabupaten Sumedang belum optimal dalam hal pengelolaan sampah dibuktikan dengan data yang telah diutarakan sebelumnya di atas, dan kenyataan dilapangan peneliti melihat masih terdapat beragam permasalah mengenai pengelolaan sampah di Kabupaten Sumedang yaitu pelayanan pengangkutan sampah belum merata dari 26 Kecamatan 12 Kecamatan saja yang dapat pelayanan pengengkutan dari Dinas Lingkungan Hidup dan Kehutanan Kabupaten Sumedang.

Peneliti menganggap hal ini cukup erotis karena 14 Kecamatan lain belum mendapat pelayanan pangangkutan, dilihat dari data di atas perkiraan sampah yang dihasilkan 2.796,50 m3 dan volume sampah yang ditangani oleh pemerintah Kabupaten melalui DLHK baru 273 m3. Dengan jumlah penduduk di atas 1 juta jiwa, hendaknha Pemkab Sumedang khususnya DLHK memikirkan model yang tepat untuk penengan dan pengelolaan sampah. Angka 273 m3 sampah yang bisa ditangani merupakan angka yang menyedihkan.

Armada pengangkat sampah di Kabupaten Sumedang dari 24 Truk sampah hanya tersedia hanya 12 Truk dalam kondisi baik, sisanya dalam kondisi rusak, DLHK merasa kewalahan dalam mengangkut sampah dalam hal ini disebebkan jumlah TPS dan armada pengangkut sampah tidak sebanding, sehingga sebagian besar sampah yang tidak terangkut terus menumpuk dikarenakan kapasitas truk pengangkut sampah yang begitu terbatas.

Dari data yang tercatat volume sampah di 12 Kecamatan yang di tangani oleh DLHK sebesar 1.743,10 dan yang baru tertangani sebesar $273 \mathrm{~m} 3$, hal ini berarti masih ada 1.470,1 m3 sampah yang belum tertangani di 12 Kecamtan tersebut. Menurut peneliti hal ini cukup memprihatinkan karena cakupan wilayah penanganan sampah ditangani saat ini saja, DLHK belum bisa menangani secara optimal.

Sistem pengelooan akhir sampah masih menggunakan open damping yakni metode penimbunan terbuka dan sering di sebut metode kuno. Pada tahap ini sampah dikumpulkan dan ditimbun begitu saja pada lubang yang dibuat pada suatu lahan hingga menumpuk tanpa dilapisi dengan lapisan geotekstil dan saluran lindi. Cara ini sudah direkomendasikan oleh pemerintah pusat tetapi hal ini masih saja tetap dilakukan oleh pemerintah kabupaten Sumedang. Menurut peneliti hal ini dapat menimbulkan masalah selanjutnya bagi pemerintah Sumedang mengingat open damping sangat potensial dalam mencemari lingkungan, baik itu dari pencemaran air lindi/air sampah yang menyerap kedalam tanah yang dapat mencemari sumur ataupun sumber mata air masyarakat di Sumedang.

Berdasarkan fenomena tersebut, peneliti melihat bahwa mengatasi permasalahan dalam penegelolaan sampah Kebupaten Sumedang diperlukan cara yang tepat. Sehingga Dinas Lingkungan Hidup dan Kehutanan Kabupaten Sumedang sebagai bertanggung jawab atas sampah yang ada di Kabupaten Sumedang harus mampu mengembangkan profesionalnya dalam pengelolaan sampah.

\section{B. TINJAUAN PUSTAKA}

\section{Administrasi Publik}

Administrasi Publik menurut Suradinata dalam Saebani (2012) berasal dari ilmu politik yang ditujukan agar kegiatan kenegaraan dapat berjalan sesuai dengan tujuan yang telah ditetapkan. Administrasi publik berperan dalam perumusan kebijakan negara 
sebagaimana Menurut Nigro dalam Saebani (2012) mengatakan bahwa administrasi publik sebagai berikut administrasi publik peranannya sangat penting dalam perumusan kebijakan Negara dan karena itu merupakan bagian dari proses politik (public administration has an important role in the formulation of public policy and is thus part of the political process)".

Sejalan dengan pendapat tersebut, Chandler dan Plano dalam Saebani (2012) mengatakan bahwa administrasi publik adalah proses mengimplementasikan kebijakan. administrasi publik berfokus pada penegakkan hukum, proses pembuatan, dan penerapan peraturan, serta regulasinya dalam menyelenggarakan kebijakan publik.

Chandler dan Plano dalam Pasolong (2013) menjelaskan bahwa administrasi publik merupakan seni dan ilmu (art and science) yang ditujukan untuk mengatur public affairs dan melaksanakan berbagai tugas yang ditentukan.

Defnisi ini lebih menekankan lembaga-lembaga Negara sebagai pelaksana fungsi eksekutif, legislatif, dan yudikatif dalam penyelenggaraan kepentingan publik. Di mana yang menjadi komponen dalam administrasi publik adalah organisasi, personalia, dan keuangan.

\section{Kebijakan Publik}

Istilah kebijakan digunakan untuk menunjuk perilaku seorang aktor atau sejumlah aktor dalam suatu bidang kegiatan tertentu. Thomas R. Dye dalam Islami (2009) mendefinisikan kebijakan publik sebagai "Is whatever governments chose to do or not to do", yaitu dapat diartikan sebagai apapun yang dipilih oleh pemerintah untuk dilakukan atau tidak dilakukan. Dye mengatakan bahwa bila pemerintah memilih untuk melakukan sesuatu maka harus ada tujuannya (obyektifnya) dan kebijakan publik itu.

Definisi kebijakan publik dari Dye tersebut menurut Subarsono (2013) mengandung makna bahwa kebijakan publik tersebut dibuat oleh badan pemerintah bukan organisasi swasta, serta kebijakan publik menyangkut pilihan yang harus dilakukan atau tidak dilakukan oleh pemerintah. harus meliputi semua tindakan pemerintah atau pejabat pemerintah saja".

Edward III dan Sharkansky dalam Islami (2009) mengartikan kebijakan publik yang hampir mirip dengan definisi Thomas R. Dye di atas, yang mana kebijakan publik diartikan sebagai apa yang dinyatakan dan dilakukan atau tidak dilakukan oleh pemerintah. kebijakan publik itu berupa sasaran atau tujuan program-program pemerintah.

\section{Pelayanan Publik}

Menurut Elitan dan Anatan (2007), pelayanan merupakan aktivitas-aktivitas yang tidak dapat didefinisikan, tidak berwujud, dan merupakan objek utama dari transaksi yang dirancang untuk memberikan kepuasan kepada pelanggan. Sementara menurut Kotler dan Keller (2009), pelayanan dan service adalah setiap tindakan atau kinerja yang ditawarkanoleh satu pihak kepada pihak lain pada dasarnya tidak berwujud dan tidak mengakibatkan kepemilikan sesuatu.

Pelayanan berarti melayani suatu jasa yang dibutuhkan oleh masyarakat dalam segala bidang kegiatan pelayanan kepada masyarakat merupakan salah satu tugas dan fungsi administrasi publik. 


\section{Pengelolaan Sampah}

Pengelolaan dapat diartikan sebagai suatu kegiatan yang ditujukan untuk memanfaatkan suatu material atau fasilitas dengan tujuan tetentu yang melibatkan sumberdaya dan prosedur untuk melaksanakannya.

Menurut Kamus Besar Bahasa Indonesia penelolaan merupakan Proses, cara, perbuatan mengelola atau proses yang memberikan pengawasan pada semua hal yang terlibat dalam pelaksanaan dan pencapaian tujuan.

Tchobanoglous dalam Soma (2010) secara definisi, sampah adalah semua jenis bahan buangan baik yang berasal dari manusia atau binatang yang biasanya berbentuk padat. Umumnya bahan-bahan tersebut dibuang karena dirasakan oleh pemiliknya sebagai barang yang tidak berharga, tidak berniali, dan tidak diingainkan.

Sampah merupakan material sisa baik dari hewan, manusia, maupun tumbuhan yang tidak terpakai lagi dan dilepaskan ke alam dalam bentuk padatan, cair ataupun gas.

\section{METODE PENELITIAN}

Penelitian ini merupakan penelitian kualitatif yang merupakan suatu proses dari berbagai langkah yang melibatkan peneliti, paradigma teoritis, strategi penelitian, metode pengumpulan data, maupun pengembangan interpretasi dan pemaparan (Afifuddin dan Saebani, 2012; Moleong, 2013). Jenis data yang digunakan dalam penelitian ini adalah data kualitatif (Bungin, 2007). Teknik pengumpulan data yang digunakan dalam penelitian ini berupa observasi, wawancara dan studi dokumentasi. Dalam penelitian ini, proses analisis data yang digunakan adalah analisis data kualitatif model interaktif dari Miles dan Huberman dalam Silalahi (2009) yang terdiri dari tiga alur kegiatan yang terjadi secara bersamaan, yaitu reduksi data, penyajian data, dan penarikan kesimpulan sebagai sesuatu yang terjalin merupakan proses siklus dan interaktif pada saat sebelum, selama, dan sesudah pengumpulan data dalam bentuk sejajar untuk membangun wawasan umum yang disebut analisis.

\section{HASIL DAN PEMBAHASAN}

Peneliti dalam melakukan penelitiannya untuk menentukan kualitas pelayanan didukung oleh teori Fitzsimmons dalam Mukarom (2016). Menurut Fitzsimmons dalam Mukarom (2016) terdapat 5 faktor yang menentukan kualitas pelayanan, antara lain yaitu tangibles, reliability, responsiveness, assurance, dan emphaty.

\section{Tangibles}

Tangibles atau keterbukaan merupakan kualitas pelayanan yang berupa sarana fisik yang terlihat dan dapat dirasakan oleh semua yang merasakan pelayanan itu baikpemberi pelayanan maupun penerima pelayanan. Sarana fisik tersebut berupa fasilitas yang diberikan oleh pemberi pelayanan yaitu seperti, sarana fisik perkantoran, komputerisasi administrasi, ruang tunggu, dan tempat informasi.

Berdasarkan data pada Dinas lingkungan Hidup dan Kehutanan Kabupaten Sumedang tahun 2017 yang mana disebutkan bahwa saran prasarana yang ada di Dinas Lingungan Hidup dan Kehutanan Kabupaten Sumedang, seperti jumlah roda, motor sampah dan truk sampah yang belum menyeluruh.

Sebagaimana dari hasil wawancara berkaitan dengan tangibles pertama adalah yang disampaikan oleh Ketua Bidang Persampahan dan Pertanaman sebagai berikut: "Kualitas 
fisik dari Dinas Lingkungan Hidup dan kehutanan khususnya dibidang persampahan disebut cukup lah ya, satu kita lihat dari fisik-fisik bangunan untuk tps-tps lumayan ya walaupun kadang kala kan yang nama nya pembangunan yang ditempat sampah kita bagus ya karena orang image nya adalah sampah bagi kita sudah maksimal, bagi masyarakat mungkin karena disana ada tumpukan sampah tetep kelihatannya kurang maksimal, gitu ya. Terus mengenai kendaraan operasional yang ada fisiknya cukup juga memang ada yang sangat mengkhawatirkan". (wawancara pada tanggal 21 Oktober 2019).

Demikian juga yang kedua disampaikan oleh Kepala UPT TPA sampah Cimalaka sebagai berikut: "Kualitas yang diberikan kepada masyarakat kami berusaha semaksimal mungkin dengan memberikan pelayanan sebaik-baiknya dan sepuas-puasnya". (wawancara pada tanggal 21 Oktober 2019).

Selanjutnya yang diungkapkan oleh masyarakat warga Kecamatan Sumedang Utara sebagai berikut: "Alhamdulillah yang saya lihat dari segi inprastruktur yang diberikan pemerintah telah cukup baik contohnya adanya motor sampah dan roda sampah setiap hari. Ada juga mobil sampah yang mengangkut akan tetapi kondisi kelyakan mobil sampah seharusnya dirawat dengan baik". (wawancara pada tanggal 23 Oktober 2019).

Berdasarkan data dan hasil wawancara dengan tiga informan di atas, maka peneliti dapat menganalisis untuk dimensi tangibles dalam pelayanan pengelolaan sampah oleh Dinas Lingkungan Hidup dan Kehutanan Kabupaten Sumedang sudah cukup baik dalam segi kualitas fisik pelayanan pengangkutan dan pengelolaan sampah, namun dari segi sarana dan prasarana (alat-alat) seperti kendaraan sampah masih ada yang tidak terawat dan tidak layak pakai karena menghambat dalam pengangkutan sampah dilapangan.

\section{Reliability}

Reliability atau keandalan adalah salah satu dimensi yang menitikberatkan kepada kemampuan petugas atau pemberi pelayanan dalam melayani seluruh penerima pelayanan sesuai dengan kemampuan atau keandalan dari setiap petugas. Selain kemampuan dari petugas, kemampuan kerja dan konsistensi kerja juga diukur dalam dimensi ini.

Adapun berdasarkan wawancara dengan ketua bidang persampahan dan pertanaman sebagai berikut: "Konsentrasi dari para pemberi kebijkan dari bupati kepala dinas turun lagi kebidang itu sangat konsisten ya cuman ke konsistenanya itu kembali lagi kepada masarakat ya, kami juga dari pemerintah daerah sudah konsisten seperti kita mempunyai SOP nya harus gini harus gini tapi kita yang menjalankan kadang-kadang di masyarakat tapi kita tidak mempermasalahka masyarakatsemua apapun program ya tanpa dukungan dari masayarakat sedikit kemungkinan untuk berhasil, ini peranan masyarakat harus itu, kita konsisten ya masyarakatnya bagaimana ya alhamdulilah untuk itu, contoh-contohnya banyak lah ya dengan menurunkan program ini kita konsisten dengan ini tapi kan kembali lagi mana yang harus dikerjakan oleh kita mana yang harus dikerjakan masyarakat, kita kerjakan tapi masyarakatnya ya itu". (wawancara pada tanggal 21 Oktober 2019)

Adapun pernyataan lain yang disampaikan oleh Kepala UPT TPA sampah Cimalaka sebagai berikut: "Kualitas yang diberikan kepada masyarakat kami berusaha semaksimal mungkin dengan memberikan pelayanan sebaik-baiknya dan sepuas-puasnya". (wawancara pada tanggal 21 Oktober 2019). 
Selanjutnya pernyataan disampaikan oleh masyarakat warga Kecamatan Sumedang Utara sebagai berikut: "Selama ini yang saya lihat dan rasakan dari segi pengangkutan sampah sangan konsisten dalam mengangkut sampah ke wilayah-wilayah, akan tetapi masih banyak kendala khusus nya rumah yang tidak bisa di masuki motor sampah atau roda".(wawancara pada tanggal 21 Oktober 2019).

\section{Responsive}

Dalam dimensi responsive terdapat beberapa indikator yang salah satunya telah disebutkan d iatas, yaitu petugas harus merespon setiap keluhan dari masyarakat, petugas harus melakukan pelayanan secara cepat, petugas harus melakukan pelayanan secara tepat, petugas harus melakukan pelayanan secara cermat dan tepat waktu. Dalam ketepatan, kecermatan, dan ketanggapan seorang petugas juga diukur oleh para aparatur yang memantau dan yang mempunyai wewenang untuk meningkatkan kualitas pelayanan.

Adapun melalui wawancara dengan Kepala Bidang Persampahan dan Pertanaman sebagai berikut: "Para pelayan berarti kita para pejabatnya dengan tim kita suka ada silaturahmi dengan rekan rekan setiap siang atau sore menyampaikan permasalahanpermasalahan dilapangan nah oleh kita para pejabat yang mempunyai kebijakan langsung mencarikan solusi-solusi yang terbaik, alhamdulilah adanya kegiatan itu permasalahpermasalah dilapangan bisa diterpecahkan. Salah satu contoh gini, hari ini orang sipetugas tidak masuk itu kan masalah masyarakat kan tidak tau makannya kita backup oleh petugas yang berdekatan, kita kembali lagi ada permasalah dilapangan seandainya ada orang yang mempunyai hajatan salah satu kasus berarti kan timbunan sampahnya banyak nah apakah sipetugas harus mengangkut yang banyak ini atau meninggalkan yang lain karena apa mungkin dengan hajatan ini bisa satu roda untuk satu lokasi sementara satu roda ini sekitar 20 KK seharinya berarti kan permasalahan nya itu jadi seandainya tidak terangkut itu dipecahkan salahsatunya kita bantu kendaraan”. (wawancara tanggal 21 Oktober 2019).

Demikian pula disampaikan juga oleh Kepala UPT TPA sampah Cimalak sebagai berikut: "Aparatur DLHK Kabupaten Sumedang ikut serta dalam pemecahan masalah bersama masyarakat dan tokoh-tokoh setempat untuk memecahkan permasalah-permasalah di lapangan. Para pegawai memberikan kontribusi kepada masyarakat dan konsisten dalam memberikan pelayanan". (wawancara pada tanggal 21 Oktober 2019).

Lalu disampaikan pula oleh pasukan kuning sebagai berikut: "Jadi saya mah tidak diikutsertaan dalam memecahkan masalah soal sampah kita mah fokus melayani masyarakat pengangkutan sampah, kami hanya menerima intruksi dari atasan jdi soal ikut serta kami diikutsertakan jang dalam pembahasan anggaran, soal masalah sampah dll”. (wawancara pada tanggal 21 Oktober 2019).

\section{Assurance}

Assurance atau jaminan menurut Fitzsimmons dalam Mukarom (2016:68) adalah kemampuan dan keramahan serta sopan santun petugas dalam meyakinkan kepercayaan konsumen atau penerima pelayanan. Assurance atau jaminan adalah kepastian yang diperoleh dari sikap sopan santun petugas, komunikasi yang baik, dan pengetahuan yang dimiliki, sehingga mampu menumbuhkan rasa percaya pelanggan atau konsumen. 
Dalam assurance atau jaminan menurut Fitzsimmons dalam Mukarom (2016:68) terdapat beberapa indikator untuk mendukung pelayanan yang berkualitas yaitu petugas harus memberi jaminan tepat waktu dalam pelayanan, petugas memberi jaminan biaya dalam pelayanan, petugas memberi jaminan legalitas dalam pelayanan, petugas memberi jaminan kepastian biaya dalam pelayanan.

Indikator-indikator di atas dapat dilakukan dengan baik apabila petugas maupun pemegang wewenang dapat menyampaikan dan mensosialisasikan secara baik. Pemegang wewenang tersebut juga menentukan bagaimana pelayanan yang berkualitas itu ditentukan dari penyampaian yang dilakukan.

Seperti hasil wawancara peneliti dengan Kepala Bidang persampahan dan pertanaman Dinas Lingkungan Hidup dan Kehutanan Kabupaten Sumedang sebagai berikut: "Ya kembali lagi kita punya SOP kita coba memberikan yang terbaik da kita mah orang timur hade goreng ku bahasa. Kadang kadang rekan-rekan dilapangan diberbagai permsalahan tetap kita memberikan yang terbaik senyum sapa”. (wawancara pada tanggal 21 Oktober 2019).

Kemudian disampaikan pula oleh Kepala UPT TPA sampah Cimalaka sebagai berikut: "Alhamdulillah memberikan keramahan dengan baik dan suport kepada masyarakat untuk membuang sampah pada tempatnya dan tidak memberikan pungutan atau iuran kepada masyarakat terhadap pelayanan sampah dan itu gratis". (wawancara pada tanggal 21 Oktober 2019).

Lalu disampaikan pula oleh salah seorang masyarakat Kecamatan Sumedang Utara sebagai berikut: "Sampai sejauh ini para petugas sudah ramah kepada masyarakat. Karena setiap pengangkutan juga alhamdulillah senyum sapa meraka ada sering juga gitu ada”. (wawancara pada tangal 21 Oktober 2019).

Kemudian adapun sopan satun pelayanan yang diberikan di Dinas Lingkungan Hidup dan Kehutanan Kabupaten Sumedang seperti yang disampaikan oleh Kepala Bidang persampahan dan Pertanaman Kabupaten Sumedang sebagai berikut: "Yang namanya sopan santu ya itu kewajiban kita tapi kadang-kadang kita memberikan kesopanan ya karena ada image dari masyarakat kita pekerja dilapangan seperti itu tolong kembalikan lagi, kita sopan kadang-kadang karena kita tukang sasapu dijalan kadang kurng dihormati, tapi tetep kita memberikan yang terbaik kepada msayarakat kita punya SOP". (wawancara pada tanggal 21 Oktober 2019).

Kemudian disampaikan pula oleh Kepala UPT TPA sampah Cimalaka sebagai berikut: "Untuk sopan santu ya harus namanya juga kita sebagai aparatur pemerintah harus memeberikan yang terbaik buat masyarakat karna dengan sopan santun kita bisa memberikan keramahan buat masyarakat sendiri dan alhamdlillah masyarakat pun kepada kami juga memberikan sopan santun alhamdulillah". (wawancara pada tangal 21 Oktober 2019).

\section{Emphaty}

Dalam dimensi emphaty atau sikap tegas yang diberikan petugas kepada para penerima pelayanan dengan penuh perhatian. Selain itu, pelayanan yang baik juga harus didasarkan kepada kemampuan menanggapi atau rasa pengertian kepada penerima pelayanan. Sikap yang dimiliki oleh petugas adalah harus sabar karena setiap keluhan masyarakat akan selalu ada dan rasa perhatian juga sangat perlu dilakukan agar meningkatkan kepuasan atas pelayanan yang diberikan juga peningkatan dalam pelayanan tersebut. 
Dalam dimensi emphaty menurut Fizsimmon dalam Mukarom (2016: 68) menyebutkan bahwa terdapat beberapa indikator pendukung demi terciptanya kualitas pelayanan yang memuaskan masyarakat antara lain, mendahulukan kepentingan masyarakat, petugas melayani dengan sikap ramah, petugas melayani dengan sikap sopan santun, petugas melayani dengan tidak membeda-bedakan, petugas melayani dan menghargai setiap penerima pelayanan.

Dari indikator-indikator di atas sangat jelas bahwa dalam meningkatkan suatu kualitas pelayanan sangat diperlukan attitude atau sikap dari petugas itu sendiri, dan jangan mencampur adukkan urusan pribadi dengan penerima pelayanan agar tidak menimbulkan suatu penilaian yang buruk untuk satu instansi tersebut.

Sikap-sikap di atas akan lebih baik lagi jika petugas atau pemegang wewenang selalu menyampaikan dan memberi himbauan kepada petugas lainnya untuk selalu bersikap baik dan ramah agar tercipta rasa kepusan dari masyarakat itu sendiri. Berikut adalah wawancara dengan Kepala Bidang persampahan dan pertanaman Dinas Lingkungan Hidup dan Kehutanan Kabupaten Sumedang menanggapi dari setiap indikator yang ada di dimensi emphaty ini sebagai berikut: "Sikap tegas kepada petugas dan masyarakat kami itu kadangkadang kita tegas tapi semua orang masyarakat kan beda-beda kadang dibilang galak atau apa tapi tetep kita mah senyum sapa aja karna kita pemerintah untuk membantu masyarakat khususnya di persampahan". (wawancara pada tanggal 21 Oktober 2019).

Kemudian disampaikan pula oleh Kepala UPT TPA sampah Cimalaka sebagai berikut: "Alhamdulillah kami setiap ada yang melanggar aturan yang ada di TPA ataupun dilapangan kami memberikan sikap tegas kepada para Masyarakat maupun kepada para petugas lapangan lainnya bukan memarahi tapi sikap tegas sekaligus memberikan arahan untuk mengikuti Aturan yang ada disini”. (wawancara pada tanggal 21 Oktober 2019).

Lalu disampaikan pula oleh salah seorang masyarakat Kecamatan Sumedang Utara sebagai berikut: "Untuk sikap tegas memang suka ada contohnya kalau misalkan kami dan warga lainnya jika ada sampah yang belum terkumpul ditempatnya kadang para pemberi pelayanan suka ada teguran atau arahan bagikami karna kadang-kadang kan kami suka lupa atau sibuk dengan urusan lainnya, kadang belu dikeluarkan kadang suka masih belum terkumpul itu suka ada teguran bagi kami”.'(wawancara pada tanggal 21 Oktober 2019)

Selanjutnya disampaikan pula oleh petugas pasukan kuning sebagai berikut: "Untuk sikap tegas ya kami mah suka memberikan ketegas kepada para warga ya kaya misalkan sampah belum di simpan dipinggir jalan atau masih belum terkumpul itu kami suka kesel, keselnya ya disaat saya sudah pergi kadang suka siangnya ada yang menyimpan takunya ya kalau ujan kan itu terbawa arus kadang mah". (wawancara pada tanggal 21 Oktober 2019).

Kemudian adapun sikap penuh perhatian pelayanan yang diberikan di Dinas Lingkungan Hidup dan Kehutanan Kabupaten Sumedang seperti yang disampaikan oleh Kepala Bidang persampahan dan Pertanaman Kabupaten Sumedang sebagai berikut: "Kita itu memberikan reward saja kadang-kadang konismen nya, yang penting kita tidak ada sampah, bingungkan secara langsung ada masyarakat yang tidak membayar retribusi ada juga yang ada kita bingung sama yang rajin membayar retribusi apakah yang tidak bayar tidak di angakat enggakkan harus dibawa tetep karna kita pemerintah untuk melayani masyarakat". (wawancara pada tanggal 21 Oktober 2019). 
Kemudian disampaikan pula oleh salah satu masyarakat Kecamatan Sumedang Utara sebagai berikut: "Sikap perhatian para petugas disini dibuktikan dengan membantu mengangkut sampah dari gang-gang kecil seperti di daerah perkotaan yang tidak bisa di jangkau oleh motor dan roda sampah”. (waancara pada tanggal 21 Oktober 2019).

Berdasarkan hasil wawancara di atas peneliti dapat menganalisis untuk dimensi emphaty (empati) itu dalam pelayanan pegawai Dinas Lingkungan Hidup dan Kehutanan Kabupaten Sumedang sudah terbilang baik dilihat dari sikap tegas petugas kepada masyarakat terbilang baik, sikap tegas tersebut dilihat dari pemberian sosialisasi pelayan terhadap masyarakat tentang pentingnya membuang sampah pada tempatnya dan pemeberian sosialisasi tentang dampak buruk apabila warga atau masyarakat membuang sampah tidak pada tempatnya.

Kemudian sikap penuh perhatian yang diberikan pelayan pada masyarakat terbilang baik juga dengan dibuktikan adanya pengangkutan sampah dari gang-gang kecil dengan bantuan roda sampah. Hal tersebut rutin dilakukan oleh pasukan kuning yang telah diaahkan oleh petugas Dinas Lingkungan Hidup dan Kehutanan Kabupaten Sumedang. Dengan demikian, dapat disimpulkan bahwa terdapat beberapa aspek yang mendukung dari indikator yang ada di dimensi emphaty ini, yang mana indikator- indikator tersebut sudah mencakup seluruh aspek dalam kualitas pelayanan menurut Fitzsimmon dalam Mukarom (2016).

\section{E. KESIMPULAN}

Berdasarkan penelitian mengenai pelayanan pegawai Dinas Lingkungan Hidup dan Kehutanan Kabupaten Sumedang dalam pengelolaan sampah yang mengacu pada lima dimensi analisis pelayanan, empat dimensi sudah berjalan dengan baik, dan satu dimensi dimensi belum berjalan dengan baik. Dimensi Tangibel, dalam pengelolaan sampah, ini merupakan dimensi yang belum berjalan dengan baik, dimana hambatannya yaitu kendaraan oprasional untuk mengangkut sampah masih adanya kendaraan yang fisiknya kurang baik. Dimensi Reliability, dalam pengelolaan sampah ini belum berjaln dengan baik, karena belum menyeluruhnya dalam pengangkutan sampah di wilayah-wilayah Kabupaten Sumedang. Dimensi Responsivess, dalam pengelolaan sampah ini sudah berjalan dengan baik, karena dapat dilihat dari perilaku petugas dalam menanggapi dan melayani masyarakat sudah secara tepat dan cepat karena para petugas telah melakukan SOP dari Dinas Lingkungan Hidup dan Kehutanan Kabupaten Sumedang. Dimensi Assurance, dalam pengelolaan sampah ini sudah berjalan dengan baik, karena dilihat dari keramahan dan sopan santun yang diberikan oleh pegawai Dinas Lingkungan Hidup dan Kehutanan Kabupaten Sumedang. Dimensi Emphaty, dalam pengelolaan sampah ini sudah berjalan dengan baik, karena sudah terbilang baik.

\section{DAFTAR PUSTAKA}

Anant, E. S. (2013). Peran Dinas Kebersihan dan Pertanaman dalam Pelaksanaan Pengelolaan Sampah di Kabupaten Sidoarjo. (Skripsi, Universitas Pembangunan Nasional "VETERAN" Jawa Timur).

Anggara, S. (2014). Kebijakan Publik. Bandung: Pustaka Setia.

Agustino, L. (2010). Implementasi Kebijakan Publik Model Van Meter dan Van Horn. Jakarta: Rajawali Press. 
Badan Perencanaan Pembangunan Daerah Kabupaten Sumedang. (2014). Permasalahan Sampah di Kabupaten Sumedang. Sumedang: Bappeda Kabupaten Sumedang.

Dewi, T. Q. (2007). Penanganan dan Pengelolaan Sampah. Jakarta : Penebar Swadaya.

Engkus, E. (2017). Implementasi Undang-Undang Perdagangan: Implikasinya Dalam Kebijakan Pengendalian Harga Kebutuhan Pokok Masyarakat, JISPO: Jurnal Ilmu Sosial dan Ilmu Politk, 18(1), 1-144.

Engkus, E. (2017). The Influence Of Organizational Behavior On Work Ethics Employees In Bandung Regency Government. IASET,1(1), 1-16.

Hamdi, M. (2014). Kebijakan Publik. Bogor: Ghalia Indonesia.

Handayaningrat. (2002). Pengantar Studi Ilmu Administrasi dan Manajemen. Jakarta: Haji Mas Agung.

Hardiansyah. (2011). Kualitas Pelayanan Publik. Yogyakarta: Gava Media.

Hasibuan M. S. P. (2008). Manajemen Sumber Daya Manusia. Jakarta: Bumi Aksara

Henry, N. (1995). Administrasi Negara dan Masalah-masalah Publik. Jakarta: Raja Grafindo Persada.

Hidayat, A. (2017). Reformasi Administrasi, Teori dan Aplikasi. Bandung. Fisip Unpas Press.

Ishak, D., Maolani, D. Y., dan Engkus, E. (2017). Konsep Kinerja Dalam Studi Organisasi Publik. JISPO: Jurnal Ilmu Sosial dan Ilmu Politk, 7(2), 101-120.

Keban, T. Y. (2004). Enam Dimensi Strategis Administrasi Publik, Konsep, Teori dan Isu. Yogyakarta: Gave Media

Kumorotomo, W. (2015). Etika Admminstrasi Negara. Jakarta: Raja Grafindo Persada.

Laporan Akuntanbilitas dan Kinerja Intansi Pemerintah Daerah Dinas Lingkungan Hidup dan Kehutanan Kabupaten Sumedang tahun 2017.

Mochamad, R. Y. (2017). Peran Dinas Lingkungan Hidup (DLH) Kota Cirebon dalam Pengelolaan Sampah tahun 2016. (Skripsi, Universitas Muhammadiyah Yogyakarta).

Moleong, L. J. (2011). Metode Penelitian Kualitatif. Bandung: Remaja Rosadakarya.

Moleong, Lexy. (2007). Metode Penelitian Administratif. Bandung: Alfabeta.

Mulyadi, D. (2016). Studi Kebijakan Publik dan Pelayanan Publik. Bandung: Alfabeta.

Nurfitriana, A. P. (2013). Pengaruh Partisipasi Masyarakat terhadap Implementasi Kebijakan Pengelolaan Sampah di Kecamatan Cibiru Kota Bandung. (Skripsi, Universitas Islam Negri Sunan Gunung Djati Bandung).

Pasolong, H. 2013. Metode Penelitian Administrasi Publik. Bandung: Alfabeta.

Pasolong, H. 2017. Teori Administrasi Publik. Bandung: Alfabeta.

Peraturan Daerah Kabupaten Sumedang Nomor 2 Tahun 2014 Tentang Pengelolaan Sampah Sejenis Rumah Tangga di Kabupaten Sumedang.

Peraturan Bupati Sumedang Nomor 12 Tahun 2017 Tentang Uraian Tugas Jabatan Struktural Pada Dinas Lingkungan Hidup dan Kehutanan.

Sastrawijaya, A.T. (1999). Pencemaran Lingkungan. Jakarta: Rineka Cipta.

Silalahi, U. (2012). Metode Penelitian Sosial. Bandung: Refika Aditama.

Silalahi, U. (2009). Studi Tentang Ilmu Administrasi: Konsep, Teori dan Dimensi. Bandung: Refika Aditama.

Subarsono. (2005). Analisis Kebijakan Publik: Konsep, Teori dan Aplikasi. Yogyakarta: Pustaka Pelajar.

Subarsono, A. G. (2005). Analisis Kebijakan Publik. Yogyakarta: Pustaka Pelajar.

Sugiyono. (2017). Metode Penelitian Kuantitatif Kualitatif. Bandung: Alfabeta.

Suparman, N., Chandra, D., \& Sari, A. L. (2019). Bureaucratic Behavior in the Implementation of Capital Expenditure Budget in the Office of Public Work and Spatial Planning of Sumedang Regency. Jurnal Bina Praja: Journal of Home Affairs Governance, 11(1), 99-109.

Taufiqurakhman. (2014). Kebijakan Publik, Pendelegasian Tanggung Jawab Negara Kepada 
Presiden Selaku Penyelenggara Pemerintahan. Jakarta: Universitas Moestopo Beragama Perss.

Wahab, S. A (2012). Analisis Kebijakan: Dari Formulasi ke Penyusunan Model-Model Implementasi Kebijakan Publik. Jakarta: Bumi Aksara. 